\title{
Financial Stability of Banks in Times of Crisis
}

\author{
Svetlana LANETS 1 , \\ Kaliningrad State Technical University, Russia
}

\begin{abstract}
This paper is aimed at drawing attention to the current situation and further development of the banking sector in Russia. In particular, it seeks to discuss ways to improve the financial stability of banks. The article looks at the banking system, describes the important role of banks in the economy of the country and establishes correlation between stability of banks and socioeconomic development of the country. It is underlined that the stability of banks is one of the key factors in economic growth. The article analyzes how the banking system has settled after the financial crisis. The focus of the article is on the characteristics of the current financial crisis, compares it to the previous ones and describes the impact of the crisis to the banks. In particular, in the frame of this publication we present the analysis of the features of crisis impact on regional banks and the possibility of losing them in near future. This paper emphasizes the impact of the banking system on the country's economy and demonstrates the importance of financial stability of the banks. Moreover the article underlines a set of financial - economic/bank government approaches to the issue of improving financial stability in the contemporary financial crisis. The paper summarizes the government role in the time of modern financial crisis and describes the existing strategies of the state. At the same time article shows the dual role of the government activities in preventing to put the finance sector under such stress as on the one hand it helps banks to increase the capitalization of banks while on the other hand it introduces Basel 3 principles, which reduce capital. The study is based on the methods of analysis, comparison, statistical data and theoretical generalization. The scientific and theoretical part of the survey is based on the official statistics and data from the Central Bank. We believe that the issue of bank's stability, especially in this uncertain time, has not received sufficient attention, and the application of banks stability in man-aging development remains limited. The study of underlying facts showed the necessity of further government interference in order to modernize the national banking system. The findings also suggest the need for implementation of new methods for developing regional banks in order to enhance their competitiveness. The facts point to the urge to develop a more efficient system to support the current banking management.
\end{abstract}

Keywords: financial stability, financial crisis, government support, regional banks, Basel 3.

JEL Classification: G21, G28

\section{Introduction}

This article is aimed at studying a particularly burning issue, that of a bank's financial stability in the modern financial crisis. Banking system plays an important role in the socioeconomic development of the country, primarily because of certain exclusivity inherent to its functions. Banking sector is responsible for money and it is the main institutional guide in the monetary and credit policy, which supports and provides financial flows in the country. It is one of the main providers of the country's economic stability. Internal and external balances and payments rely on effective banking structure. Banks mobilize savings accounts, performing socially important functions. Thus, banks are one of the key actors who can contribute to the economic growth in Russia and provide general conditions for development and implementation of the right structure of an effective and modern banking system.
Instability of the banking system could lead to the disruption of economy and could destabilize social and political situation in the country. Thus, the role of the banking sector in economy of the country takes the utmost importance, and the question of its stable functioning in today's financial crisis becomes especially valid. The stability of banks affects the rate of the country's socioeconomic development, whereas the banks' instability can aggravate existing economic and social problems that various strategies and programs of the federal government are created to solve.

\section{Banking Crisis in Russia}

Banking crises in Russia take place every five years, give or take. The current stage of the development of Russian banking sector is facing the fourth crisis in the last twenty years of a full-blown crisis (1995, 1998, 2008, 2014-2015).

At the same time, the current crisis situation is much worse than in 2008. Some of the problems can be

\footnotetext{
Corresponding author

${ }^{1}$ Department of Finance and Credit, Kaliningrad State Technical University.

E-mail: LanetsSV@gmail.com
} 
compared to the ones that emerged during the previous crises, while some of them are totally different and will have stronger repercussions. Nowadays, the problems of the banking sector are based on toxic loans and on preference for liquidity at the expense of profitability. The situation is worse because of shocks associated with the fall of ruble, the stagnation in the real sector and with budgetary problems.

Sanctions for Russia only added insult to injury (Petrova, 2014). Russia faced deterioration of external conditions: a complication of relations with Western countries, narrowing of the possibilities of attracting external funding, a decline in the oil prices. With limited access to international capital markets, local businesses have increased the demand for foreign currency in the domestic market to pay off external debt (Khlopunova, 2015).

The following table compares the data in times of banking crises, according to statistics from the Bulletin of the Bank of Russia for 1998, 2008, 2014 and 2015.

It is important to note that the reason for the drop in the indicators for the banks is not only a crisis of the banking system, but also the requirement of the Central Bank in cooperation with the Ministry of Finance to increase the minimum capital of commercial banks up to $300 \mathrm{mln}$ rubles in 2015, which has led to the consolidation of banks.

High rate of license revocation begs to consider the overall stability of the banking system. For the first time in many years, the banks have shown a negative result. According to the credit reporting companies posted on the website of the Central Bank, in January - September 2015 the banking system received 128.38 billion rubles of profit. At the same time the profit for the same period in previous year was 685.2 billion rubles.

Below is a ranking of banks based on the ratio of profit from the beginning of the year (according to kuap.ru).
The main reason for increased losses is the increase of reserves for possible loan defaults. It is worth noting that the cost of raising funds by banks remains high, which leads to a decrease in the interest income of credit institutions.

\section{The government's Role in the Crisis}

The sanctions and the cut off from Western money happened to be a reason for the banks to be heavily dependent on funding from the Central Bank of Russia and the dynamics of the interest rate. Big banks have to finance loss-making enterprises on favorable terms, which will inevitably break the balance sheet and reduce the profitability of a bank. Moreover, there is a growth of overdue debts of borrowers in all segments in crisis time. When the state enters in capital with the large quantities, banks lose independence in decision-making process and reduce the quality of their asset management.

There are some problems for large banks, namely: an increase in the load on the external debt of the banks, substituted domestic sources of external funding, low desire to lend, increased competition for creditworthy borrowers. The problem of the growth of overdue loans also increases, which affects the Bank's results: increased payments to the bank's reserves for loan losses lead to a decrease in profitability of the banking sector.

Banks now mainly rely on government support, and the state is starting to deliver. The situation is ambiguous at best: on the one hand, the government supports the banking system by increasing the capitalization of banks, on the other hand, it introduces Basel principles, which reduce capital.

The Central Bank of Russia with regard of the criteria of the international activities identified systemically important credit institutions in Russia. The list of systemically important banks includes four state Banks

Table 1

Comparison of Banking crises in 1998, 2008 and 2014-2015

\begin{tabular}{|l|c|c|c|c|}
\hline \multicolumn{1}{|c|}{ Index } & 01.09 .98 & 01.09 .08 & 01.09 .14 & 01.09 .15 \\
\hline Registered credit institutions & 2504 & 1250 & 1057 & 1035 \\
\hline Registered banks & 2476 & 1194 & 985 & 959 \\
\hline $\begin{array}{l}\text { Credit institutions that have had their banking operations licenses revoked } \\
\text { (canceled) }\end{array}$ & 950 & 123 & 188 & 261 \\
\hline
\end{tabular}

Table 2

The ratio of profits from the beginning of the year, thous. Rub.

\begin{tabular}{|c|l|c|c|c|c|}
\hline № & \multicolumn{1}{|c|}{ Bank name } & 01.01 .2015 & 01.10 .2015 & Change absolute & Change, $\%$ \\
\hline 1 & SBERBANK OF RUSSIA & $305,703,229$ & $144,432,688$ & $161,270,541$ & $111.7 \%$ \\
\hline 2 & ALPHA BANK & $48,823,474$ & $27,679,459$ & $21,144,015$ & $76.4 \%$ \\
\hline 3 & VTB24 & $31,534,739$ & $-12,179,816$ & $43,714,555$ & $-358.9 \%$ \\
\hline 4 & Raiffeisenbank & $24,788,043$ & $10,004,522$ & $14,783,521$ & $147.8 \%$ \\
\hline 5 & VTB & $20,007,291$ & $56,447,751$ & $-36,440,460$ & $-64.6 \%$ \\
\hline 6 & GAZPROMBANK & $18,283,177$ & $-56,824,981$ & $75,108,158$ & $-132.2 \%$ \\
\hline 7 & Bank FC OTKRITIE & $14,584,843$ & $8,046,504$ & $6,538,339$ & $81.3 \%$ \\
\hline 8 & National Clearing Centre & $11,312,981$ & $14,866,102$ & $-3,553,121$ & $-23.9 \%$ \\
\hline 9 & RUSSIA & $10,087,888$ & $1,969,303$ & $8,118,585$ & $412.3 \%$ \\
\hline 10 & Rosbank & $9,658,208$ & $-2,315,502$ & $11,973,710$ & $-517.1 \%$ \\
\hline
\end{tabular}


(Sberbank, VTB, Gazprombank and Rosselkhozbank), three private banks (Alfa-Bank, "FC Opening" and PSB) and three foreign-owned banks (UniCredit Bank, Rosbank, Raiffeisenbank). These credit institutions (including the Russian credit organizations - participants of the respective banking groups) account for $63 \%$ of the entire Russian assets (based on data from October 1, 2015).

Requirements for short-term liquidity indicator of compliance (Basel III) will be used as the prudential norms established for systemically important banks in accordance with Article 57 of the Federal Law "About the Central Bank of the Russian Federation (Bank of Russia)", from October 1, 2015. The minimum allowable value of the index is set at $60 \%$ with an increase on 10 percentage points each year since 1 January 2016 up to the value of $100 \%$ at January 1, 2019.

The CBR spokesperson has announced that the Central Bank plans to introduce a surcharge to the basic capital based on "Basel III», starting on January 2016. The requirements will be phased in from January 2016 to January of 2019, in accordance with the standard calendar for «Basel III». It is about three allowances: capital conservation buffer, countercyclical buffer and Buffer to maintain capital adequacy of systemic importance.

The size and the procedure of counter cyclical buffer will be determined by the Central Bank when the regulator will consider that credit growth leads to an unacceptable level of systemic risk. At the same time in 2016 it is expected to set off with a value of zero, which is justified as we are facing reduction in the lending sector.

The buffer to maintain capital adequacy for the systemic importance of the above-mentioned systemically important financial institutions is planned at the amount of $0.15 \%$ of the risk-weighted assets with a phased increase annually by $1 \%$ by January 1,2019 .

Capital conservation buffer is planned for all banks on a consolidated basis. Based on the Basel III, it is set to start on January 1, 2016 with the amount of $0.625 \%$ of risk-weighted assets with an of increase 0.625 percentage points annually up to $2.5 \%$ by 1 January 2019 (Koroleva, 2015).

Capital conservation buffer is planned in order to cover losses in the period of financial instability, which is observed in Russia at the moment.

At the same time, large banks are more stable as they have access to cheap funding of the Central Bank. They were able to recapitalize through the OFZ. At the same time, the level of confidence of the major banks higher in an ongoing process of review and restructuring of licenses in the market.

\section{Regional Banks Problems}

The main trend of the regional banking sector development in Russia is the reduction of the number of regional banks and the concentration of assets in the largest banks. If we keep on this trend regional banks may simply disappear in the near future.
At the same time, large banks often do not reach small towns, because they are only interested in the most profitable regions. Therefore, lending to local people and businesses, although at a significantly high rate of interest, usually engaged with regional banks. It is also assumed that regional banks show a higher level of social responsibility, as local banks are focused on long-term cooperation with the community and regional business, and as a consequence, they are more interested in the balanced development of regions. Thus, we can say that regional banks form the financial systems in the region.

This underlines the need to save the system of regional banks. Despite this, government only supports large systemically important credit institutions, leaving smaller banks to fend for themselves, which makes them offer high deposit rates and risk the displeasure of the Central Bank.

According to the Central Bank (statement from 01.09.2015) there are 774 registered regional banks, a number significantly lower than that given on 01.12.2011 (982 banks). At the same time, in the Kaliningrad region, there are 23 branches of operating credit institutions and only one of them is a regional bank.

This is a call for the government to pay more attention and to apply tactics change in order to save not only the "big players", but also smaller banks. At the moment we are seeking to develop practical approaches to create the conditions, which will allow regional banks to fully implement their investment opportunities.

\section{Conclusions}

The results of this study show that the current financial crisis, which has had a serious impact on the banking sector and on the market relations in the country by hindering its socioeconomic progress, confirmed the failure of forecasting activities, and stressed the need for constant monitoring, analysis and modernization of the banking system to maintain its financial stability. It is necessary to understand the importance of the banks ability to respond to the changes of the economic, political, social and internal environment and the need of organizing the banks activity, which is based on these findings.

The financial crisis underlined the need to develop a set of methods to overcome the crisis in the banking sector, to identify ways and means of increasing the financial stability of banks, to restore confidence in the banking system and further development of the Russian banking system in the post-crisis time. With the success of these methods and management practices banks can compete and develop and that determines the future of the Russian economy.

It is obvious that the government should introduce new methods, which would be aimed at mitigating the negative effects of the banking crisis. At the same time, it is important to understand that the conditions for the restoration of the banks during the crisis suggest the invention of new methods of organization and conduct of activities by banks, which should be based on detailed analysis of the risks which the banks face. 
Vol. 1, 2015

Baltic Journal of Economic Studies

\section{References}

Cbrf.ru

Koroleva A. (2015). Banking crisis: would the large banks stand, and what about small ones? Corporate Finance, Vol 5806

Khlopunova M.V. (2015). Roots, origins and spreading of bank crisis. Novosibirsk State Technical University (NSTU), Electronic scientific journal Economics and Management of innovative technologies

Petrova S. (2014) From the stop to the crisis: Results of the year: the banking crisis began in Russia. Gazette, Vol 3746

\section{Светлана ЛАНЕЦ \\ ФИНАНСОВАЯ УСТОЙЧИВОСТЬ БАНКОВ В УСЛОВИЯХ КРИЗИСА}

Аннотация. Данная работа направлена на привлечение внимания для дальнейшего развития банковской сферы в России, в частности на повышение финансовой стабильности банков в условиях современного спада экономики. В статье рассмотрена банковская система России, описана важность роли банков в экономике страны, рассмотрена взаимосвязь между стабильностью банков и экономической ситуацией в стране и подчеркнуто, что стабильность банков является одним из ключевых факторов для роста экономики. В работе анализируется характерные особенности нынешнего финансового кризиса, сравнение его с предыдущими кризисами и описано его воздействие на банки. В частности, в рамках данной публикации предоставлен анализ особенностей влияния кризиса на региональные банки и предсказана возможность исчезновения данных банков. Статья также подчеркивает влияние банковской системы на экономику страны демонстрирует важность финансовой стабильности банков. Статья также освящает совокупность финансово-экономических отношений между банками и государством по вопросу повышению финансовой устойчивости в условиях нестабильности экономики. В работе подчеркнута важность роль государства в период финансового кризиса и описаны первые предпринятые действия. В тоже время, показана двойственность роли государства в решении проблем. С одной стороны, правительство помогает банкам, увеличивая капитализацию банков, а с другой стороны, вводит принципы Базель 3, которые снижают капитал. Исследование опирается на методы анализа, сравнения, статистической обработки данных и теоретического обобщения. Научно-теоретической базой послужили материалы центрального банка. Данная статья демонстрирует, что вопрос о стабильности банка, особенно во время финансового кризиса, не получил должного внимания, и применение существующих методов управления в банках остается ограниченным. На основе проведенного исследования выявлена и обоснована необходимость дополнительно вмешательства государства в целях модернизации национальной банковской системы в современных условиях. Также в рамках статьи подчеркнута необходимость внедрения мероприятий по развитию региональных банков для усиления их конкурентоспособности. 